\title{
Karl Barth's reflections on the Filioque
}

\section{Book Title:}

Karl Barth on the Filioque

\section{Book Cover:}

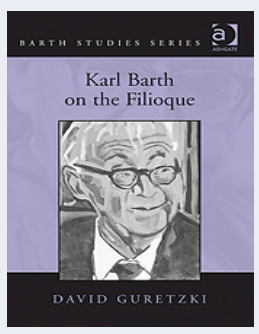

Author:

David Guretzki

ISBN:

978-0-7546-6704-9

Publisher:

Ashgate, London, 2009,

226 p., f50.00*

*Book price at time of review

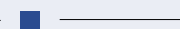

Review Title:

Karl Barth's reflections on the

Filioque

Reviewer:

Kobus Labuschagne

\section{Affiliation:}

${ }^{1}$ Faculty of Theology,

University of Pretoria,

South Africa

Email:

kobus.labuschagne@

telkomsa.net

\section{Postal address:}

Private Bag X20, Hatfield,

Pretoria 0028, South Africa

How to cite this book

review:

Labuschagne, K., 2012, 'Karl Barth's reflections on the Filioque', Verbum et Ecclesia 33(1), Art. \#575, 2 pages. http://dx.doi.org/10.4102/ ve.v33i1.575
C 2012. The Authors. Licensee: AOSIS OpenJournals. This work is licensed under the Creative Commons Attribution License.
Karl Barth (1886-1968) is not only one of the greatest theologians of all times, but he is surely also a theologian who leaves you to think twice and indeed with so much to ponder about. This book opens new insights into Barth's thinking, and contributes to the renewed interest in Barth studies.

David Guretzki's book focuses on how the Filioque, a problem of the Early Church, functions in the theological reflection of Karl Barth.

Many critics fail to distinguish between Barth's position and that of the Western Tradition of the early church, and then unfairly jump to easy conclusions. Guretzki follows the line of how Barth, without compromising himself to either the Western or the Eastern traditions of the early church, was critically engaged in a study of the Filioque. He explains how the unfolding of the Trinity and the Filioque is drawn into Barth's understanding of the self-revelation of God in Jesus Christ. Guretzki argues that Barth's teaching on Seinsweise (a term which Barth sometimes prefer, rather than person), thus on the divine modes of being, can not be identified with the Western tradition's teaching of the Holy Spirit's double procession from the persons of the Father and the Son. Barth treats this as a single procession from the common being of the one God. The reason for this lies at least partly in Barth's understanding of the perichoretic relations of the Trinity, and this, of course affects his depiction of Filioque. Barth depicts the Spirit as the One who distinguishes the Father and the Son, and at the same time upholds the unity of the Father and the Son - in a 'distinction-in-union' and in a 'union-in-distinction'. In this sense Barth identifies the Spirit, in terms of Filioque, as the Spirit of the Father and of the Son, and as such the Holy Spirit is both the bond and the boundary between the Father and the Son. To a certain extent, Barth's view can be seen as an endeavour to answer the concerns of the Eastern monopatrist tradition, the rejecting of a double source procession of the Holy Spirit. The question, however, remains whether the Western Tradition really thought in terms of a double procession. The accusation of a double source would be unfair. Guretzki emphasises that for Barth the Filioque indeed supports the Western Tradition's upholding of the full-divinity of each of the three persons or modes of being, as well as the dialectical unity of the Christology and the Pneumatology. Guretzki points out how Barth incorporates the Filioque into his cosmology (through his understanding of creation history), also into his anthropology and his soteriology. He defends Barth against the criticism of exaggerating the Christology at the expense of the Pneumatology.

Guretzki points out that Barth's adherence to the Filioque unexpectedly has a different origin and serves greater theological importance than commonly imagined. In Chapter Two of his book Guretzki identifies the origin of Barth's understanding of the Filioque already in Barth's theological work before the beginnings of the Church Dogmatics. In many cases researchers tend to come to a conclusion on Barth's defence of the Filioque solely on the basis of Barth's handling of the subject in Church Dogmatics I, 1. Guretzki reveals this as an untenable approach, and shows in his study that, though Barth remained consistent in defending the Filioque, Barth's substantiation of his argument continued to develop and even somewhat change through his ongoing development as theologian. Based on extensive research, he explains all the changes and developments in Barth's use of the Filioque from the Göttingen period up until the final volume of his Church Dogmatics.

Guretzki refers to Barth's Göttingen Dogmatics (1924), where the Filioque appears in Barth's explanation of the threefold manner of the Word of God: The preaching of the church proceeds from die revelation of God in the incarnate Word and from the written Word as testimony thereof, as the Holy Spirit proceeds from the Father and the Son. This means the interrelationship of the three forms of the Word of God (preaching, revelation, and Scripture) corresponds to a structural analogy to the relationship that the Triune God has in himself. From this it is evident that Barth does not see the Filioque as an a priori in the ontological discussion of the eternal Trinity, but as something which arose from Barth's consideration of how God revealed himself.

In Church Dogmatics III Barth refers to the Filioque in his understanding of God's creation. He points to the Holy Spirit as the ontological ground for the relationship between God and man, 
exactly because the Spirit is antecedent to this already the ontological ground for the relation between the Father and the Son, and the relation between the divine and the human in the one person of Christ. This means the Creator Father stands in relation to his creation, in Jesus Christ in the history of creation, through the Holy Spirit - the Spirit who proceeds eternally from the Father and the Son.

The significance of this study lies in Guretzki demonstrating that, despite Barth's ever-developing understanding of the Filioque through the course of his career, there is also at the same time, from beginning until end, a consistent manifestation of Barth's dialectical filioquist pneumatology.
Therefore, Barth's mature understanding of the Filioque, in consistency with his thinking from the start, reflects a dialectical understanding whereby the Spirit is portrayed as eternally involved in uniting and differentiating the Father and the Son.

The book offers a new and thorough exposition of Karl Barth's thinking on the Filioque, and is a valuable and important contribution to Barth studies as well as studies focussed on the Filioque and the Trinity. It is therefore highly recommended for theologians, students and even ordinary Christians interested in the subject. 